\title{
Postburning legume seeding in the Flooding Pampas, Argentina
}

\author{
V. F. JUAN, L. MONTERROSO, M. B. SACIDO “EX AEQUO”, M. A. CAUHÉPÉ
}

Authors are respectively, research associate, Department of Vegetal Production, Facultad de Agronomİ, Universidad Nacional del Centro de la Provincia de Buenos Aires. CC. 178 ( 7300) Azul. Argentina, and researcher, Facultad de Ciencias Agrarias, Universidad Nacional de Mar del Plata, Argentina.

\begin{abstract}
In Argentina, Paspalum quadrifarium Lam. (paja colorada) forms tall dense grassland communities in the flooding pampas. Referred to locally as "pajonales", these grasslands generally have very low nutritional value for cattle, except at the post-burn regrowth stage. To improve forage quality and consumption by breeding cattle, Lotus tenuis Walst et Kit. is over seeded immediately after burning of paja colorada pajonales. The objectives of this experiment were to follow the after seeding cover of lotus, evaluate weed control, and assess disease incidence and severity. The experiment was carried out in Azul, Buenos Aires province of Argentina, between September 1993 to September 1996. The postburn seedbed was very favorable for lotus germination and establishment. The most effective chemical weed control was obtained with 2,4-DB used alone or in combination with dicamba. Lotus increased markedly the quality of the pasture forage due to its high crude protein content. Four fungus diseases were found: Botrytis cinerea Pers., Stemphylium sp. Wallroth, Uromyces loti Blytt. and Fusarium spp. Link ex Fr. However, these caused only light foliar damage and did not impair lotus germination or establishment. The overseeding of lotus after burning of $P$. quadrifarium pajonales, is a very effective technique to improve carrying capacity and animal performance.
\end{abstract}

Key Words: Paspalum quadrifarium, Lotus tenuis, fire, weed control, diseases, species diversity

Paspalum quadrifarium Lam. (paja colorada) forms dense tall (1-1.5 m) grassland communities referred to locally "pajonales". Some researchers believe that it was the predominant vegetation of the Flooding Pampas at the end of the 19th Century (Vervoorst 1967). Because of the low carrying capacity of the "pajonales", ranchers tend to replace them with seeded pastures. There is concern about the impact that this replacement process has on the biodiversity of the region by decreasing the native fauna that is strongly attached to the pajonales communities.

Paja colorada has very low nutritional value for cattle except at the postburn regrowth stage. In vitro digestibility varies around $50 \%$, crude fiber exceeds $70 \%$ and crude protein rarely reaches $12 \%$ on a dry matter basis. Consequently, it does not provide suit-

Authors wish to thank L. Echeverrİa for facilities to work in his field; Dr. Domicio do Nascimiento Junior, S. Lerner and 2 anonymous reviewers for improving the manuscript. Financial support was provided by the U.N.C.P.B.A. project 03/A025.

Manuscript accepted 17 Aug. 1999

\section{Resumen}

En las pampas inundables de la Argentina el Paspalum quadri farium Lamb. (Paja colorada) forma densas matas de pastizal. Estas comunidades son conocidas localmente como "pajonales" y generalmente tienen muy bajo valor nutritivo para los bovinos domésticos, excepto en los rebrotes postquema.. Para mejorar la calidad de forraje y el consumo de los pajonales de paja colorada, se sobresembró Lotus tenuis al voleo postquema de dichos pajonales. Los objetivos de este experimento fueron monitorear las variaciones en la cobertura de Lotus y los demás componentes del pastizal leugo de la siembra, evaluar el control de las malezas y la incidencia y severidad de enfermedades en lotus. El experimento se condujo entre setiembre de 1993 y setiembre de 1996, en Azul, Provincia de Buenos Aires, Argentina. La cama de siembra postquema favoreció la germinación y establecimiento del Lotus. El control químico de mazezas más efectivo se obtuvo con 2,4-DB utilizado solo o en combinación con dicamba. El Lotus incrementó marcadamente la calidad del forraje del lote debido a su alto contenido de proteína cruda. Fueron determinadas 4 enfermedades fúngicas en lotus: Botrytis cinera Pers., Stemphylium sp. Wallroth, Uromycetes Loti Blytt. y Fusarium spp. Link ex Fr. las que solo causaron un ligero daño foliar y no impidieron la germinación y establecimiento de esta especie. La siembra en cobertura de Lotus immediatamente luego de la quema de los pajonales de Paspalum quadrifarium es unta técnica muy efectiva para mejorar la capacidad de carga y la respuesta animal.

able forage for young cattle or breeding females with high levels of nutrient requirements. The over seeding of lotus (Lotus tenuis Walst et Kit. is a naturalized forage legume in the region) immediately after burning of paja colorada pajonales, appears to have potential to improve forage quality and consumption by breeding cattle. However, a range of diseases caused by pathogens in Argentina (Wolcan and Dall Bello 1988, Dall Bello and Wolcan 1992) could affect the lotus survival.

The adequacy of postburned "seedbed" (formed by ashes and bare ground) for lotus germination, the competition with perennial weeds and the effect of diseases, could affect the establishment of the lotus plants. The objective of this experiment were to follow the after seeding cover development of lotus, evaluate the efficiency by weed control and to describe the diseases affecting its aerial plant parts. 


\section{Materials and Methods}

The experiment was carried out in a "pajonal" situated $70 \mathrm{~km}$ north of Azul in the center of Buenos Aires province of Argentina, between September 1993 to September 1996. The climate is sub humid and temperate (Thornthwaite and Mather 1957) with an annual rainfall of $900 \mathrm{~mm}$ and mean temperatures of $16^{\circ} \mathrm{C}$. The pajonal was covered with $70 \%$ paja colorada growing over hydromorphic soil with $\mathrm{pH}$ varying between 7.5 and 8.0 and $4 \%$ organic matter. The soil belongs to the edaphic dominion 23 group (INTA-CIRN 1989).

Four randomized $20 \times 34$ m blocks with a factorial arrangement were divided into 2 equal sized plots, 1 of which was seeded and the other remained as a control. Burning was done in early spring (12 September 1993) with prescript fire. Immediately after burning, $2 \mathrm{~kg} / \mathrm{ha}$ of scarified, inoculated and pelleted Lotus tenuis seed was hand broadcast.

Two month after sowing plots were divided into 6 subplots: control, dicamba (3,6-dichloro-2-methoxybenzoic acid) 57.5 g ai ha ${ }^{-1}, 2,4$ DB (4-(2,4-dichlorophenoxy) butanoic acid) $800 \mathrm{~g}$ ae ha-1, MCPA (4chloro-2-methylphenoxyacetic acid) $280 \mathrm{~g}$ ae ha-1, 2,4DB $800 \mathrm{~g}^{-1 e} \mathrm{ha}^{-1}+$ dicamba $57.5 \mathrm{~g}$ ai ha ${ }^{-1}$, MCPA $280 \mathrm{~g}$ ae ha ${ }^{-1}+$ dicamba $57.5 \mathrm{~g}$ ai ha ${ }^{-1}$. All treatments included a $0.2 \%$ rate of non-ionic detergent in the aspersion volume that was equivalent to 170 liter/ha. Overall, the main treatments were: seeded or control and sub-factors were 5 herbicide treatments and control. The effects were evaluated with ANOVA and means tested with the SNK test at $\mathrm{P} \leq 0.05$.

The Braun-Blanquet (1979) method was used to determine the establishment and growing of lotus, weeds, paja colorada and bare ground 2, 8, 12, 14, and 29 months after sowing. Biomass was harvested in the 12,20 , and 29 month after sowing and dry matter and crude protein determined on subsamples by standard procedures. Seedling emergence of lotus was measured by presence and abundance parameters. The effectiveness of herbicide treatments was evaluated using a visual percent scale method in which zero represents the control treatment and $100 \%$, the treatment with a total control of weeds.

Plant pathogens were studied in lotus plants. Ten, $0.5 \mathrm{~m}^{2}$ quadrats were sampled in each of the sites for 2 situations: lotus plants in associate growth with paja colorada and lotus growing in the area between paja colorada plants. The inci-

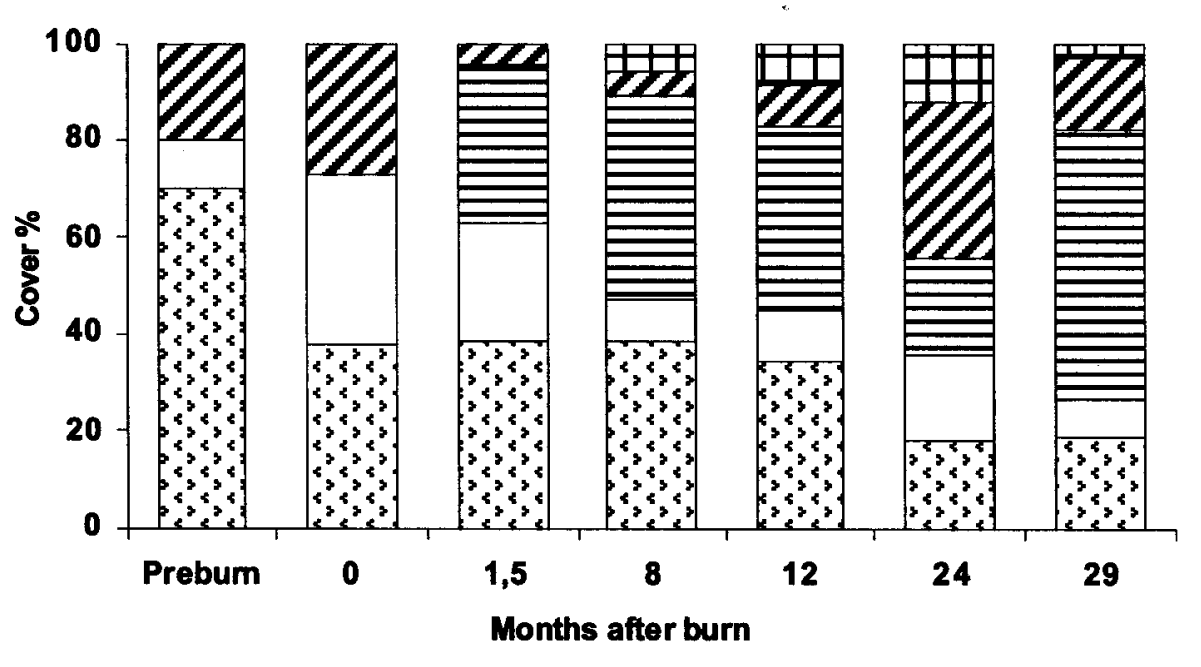

\section{¿. Paja Colorada $\square$ Weed = Lotus tenuis r. Bare Ground - Other Grasses}

Fig. 1. Cover changes occurred throughout the experimental time.

dence and severity of plant pathogens were appraised from emergence until the $24^{\text {th }}$ month by estimating the percentage of leaf and shoot area affected by disease on a visual 0-6 scale (modified from James 1971), where $0=$ no disease and $6=$ leaf/shoot very severely affected.

\section{Results and Discussion}

Vegetation cover changes after burning and lotus seeding

Figure 1 shows the changes in ground cover observed throughout the experiment. Prior to burning in September 1993, cover was made up of $70 \%$ dead paja colorada, $10 \%$ broad-leaved weeds (Plantago lance olata L., Rumex crispus L., Hydrocotyle bonariensis Lam., Mentha pulegium L., Eryngium echinatum Urban.) and $20 \%$ bare ground. A number of other weeds

Table 1. Weed cover 2 months after burning.

\begin{tabular}{lccc}
\hline \hline Species & \multicolumn{2}{c}{ Cover } & Phenological Stages \\
& Without Lotus & With Lotus & \\
\hline & $(\%)$ & $(\%)$ & Seedlings \\
Anagallis arvensis L. & 8.0 & 4.0 & Seedlings \\
Carduus acanthoides L. & 11.0 & 5.0 & Adults \\
Eryngium echinatum Urban. & 5.0 & 5.0 & Adults \\
Hydrocotyle bonariensis Lam. & 11.0 & 18.0 & Seedlings \\
Leontodon taraxacoides (Vill.) Merat & 3.0 & 3.0 & Adults \\
Mentha pulegium L. & 22.0 & 27.0 & Adults \\
Rumex crispus L. & 22.0 & 24.0 & Seedlings \\
Sonchus oleraceus L. & 8.0 & 5.0 & Seedlings \\
Stellaria media (L.) Vill. & 8.0 & 5.0 &
\end{tabular}

(Anagallis arvensis L., Carduus acan thoides L., Stellaria media (L.) Vill., Leontodon taraxacoides (Vill.) Merat, Sonchus oleraceus L.) germinated after the burning treatment.

After 45 days from sowing, lotus accounted for $33 \%$ of ground cover. Weeds cover increased to $23 \%$ and paja colorada and bare ground diminished to $40 \%$ and $4 \%$, respectively. After 8 months (Fig. 1), the cover of paja colorada and bare ground were unchanged, but lotus increased to $43 \%$ and weeds decreased to $8 \%$. A new component, other grasses, emerged with values close to $5 \%$. The decreased weed cover is associated with the chemical controls, although cover data is an average of a range of control effects given by the different herbicides used. The relationship between decreased weed cover and increased lotus cover, suggest the importance of weed suppression on lotus establishment. Once established, 
Table 2. Efficacy of chemical control.

\begin{tabular}{ll}
\hline \hline Treatment & Efficacy \\
\hline Dicamba & $(\%)$ \\
$2,4-D B$ & $21 \mathrm{~d}$ \\
MCPA & $69 \mathrm{ab}$ \\
2,4-DB + Dicamba & $54 \mathrm{bc}$ \\
MCPA + Dicamba & $79 \mathrm{a}$ \\
& $47 \mathrm{c}$ \\
\hline
\end{tabular}

lotus is highly competitive with weeds (Ortega and Laterra 1995).

After 12 months, the cover percentage of paja colorada and lotus stabilized at 37 and $40 \%$, respectively. However, during the second year, a very severe winter drought occurred which killed plants thereby increasing the proportion of bare ground. After the spring rains, lotus cover recovered and in the $29^{\text {th }}$ month occupied most of the vegetable cover. Paja colorada cover and bare ground decreased markedly. It was observed that cattle consumed a larger proportion of the paja colorada plants when lotus grew together with them. This probably explains the decrease in paja colorada cover when lotus is present.

Adults plants of Eryngium, Rumex, Mentha and Hydrocotyle spp. which were present prior to burning, sprouted after burning and did not suffered the effect of lotus presence. The annual weeds (Anagallis arvensis, Carduus acanthoides, Sonchus oleraceus and Stellaria media) germinated after burning and showed a significant lower plant cover on plots
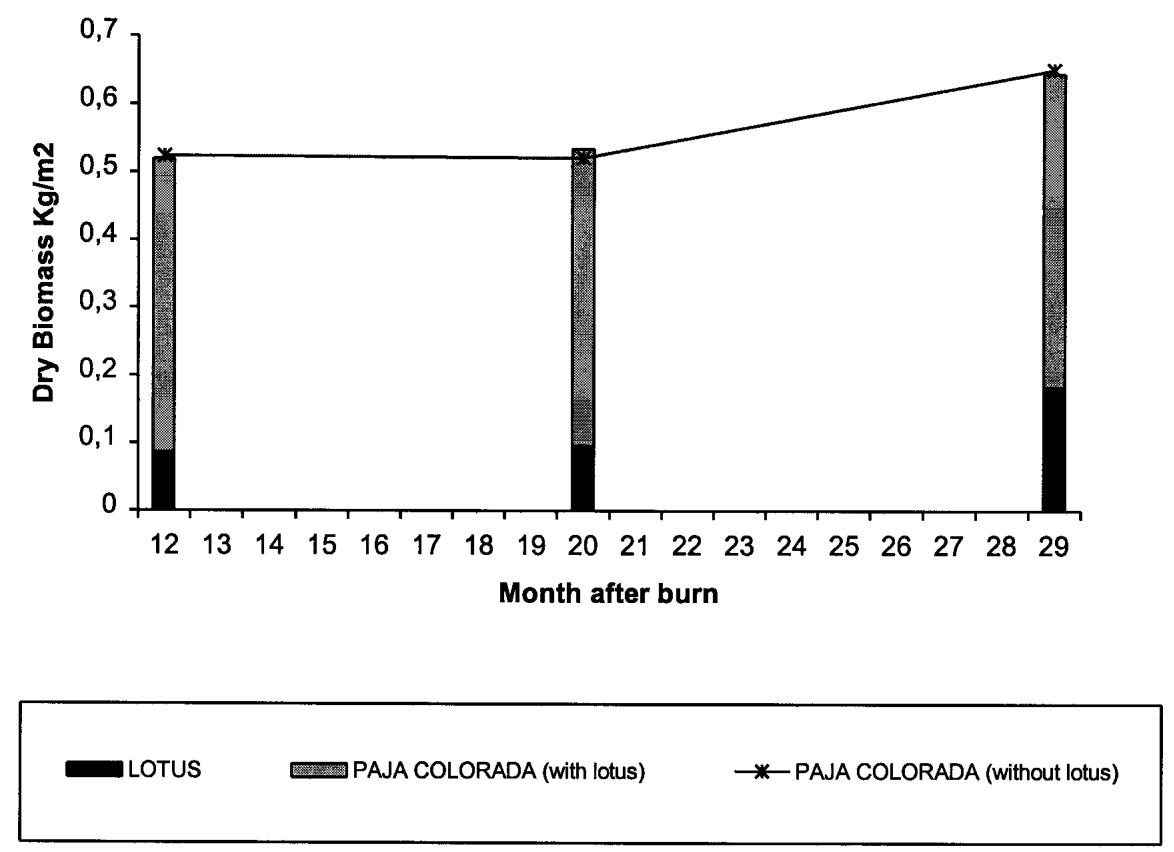

Fig. 2. Dry biomass $\left(\mathrm{kg} \mathrm{m}^{-2}\right)$ of treatments with or without lotus.

where lotus were present, as compared to plots not sown with lotus (Table 1).

The chemical control of weeds (Table 2) was equally effective for 2,4-DB when used alone or when combined with dicamba with values close to $80 \%$. The least effective treatment was with dicamba. Intermediate control was obtained with the MCPAís formulas. Due to the low presence of annual weeds, significant differences were not detected on the chemical control between lotus seeded or unseeded plots. Consequently, chemical control data was analyzed independently from the lotus seeding treatment.

Month after burn
Mixtures of 2,4-DB with dicamba, as well as dicamba used alone, were effective only with the postburn regrowth of adult plants of Rumex crispus. This species, as all the poligonacea are not satisfactorily controlled by the herbicides 2,4-D, 2,4-DB and MCPA.

\section{Biomass accumulation}

Lotus dry biomass accumulated $86 \mathrm{~g} / \mathrm{m}^{2}$ 12 months after burning and seeding which accounted for $16 \%$ of total dry biomass. The lotus biomass contribution to total biomass increased to $18 \%$ and $28 \%$ after 20 and 29 months, respectively. There was no difference in total biomass between the unseeded and seeded treatments. This indicates that the lotus growth occurred at the expense of paja colorada growth. Also it seems to show that once established, lotus has the ability to maintain or even increase pasture biomass (Fig. 2).

The crude protein content of accumulated biomass increased from $7 \%$ for paja colorada to $21 \%$ for lotus. The protein content in paja colorada is lower than the nutritional requirements for beef cattle. The lotus plots offered about $30 \mathrm{~g} / \mathrm{m}^{2}$ of crude protein compared to only $10 \mathrm{~g} / \mathrm{m}^{2}$ in unseeded plots. In earlier studies, paja colorada postburn regrowth reached a crude protein content of $12 \%$ for the first regrowth after burning, but decreased thereafter (Sacido et al. 1995). An increase in available soil nitrogen availability from $\mathrm{N}$ fixed by legumes and liberation of $\mathrm{N}$ of microbial biomass facilitated by the early heating of soil have been suggested as possible explanations for this increase in 
a)

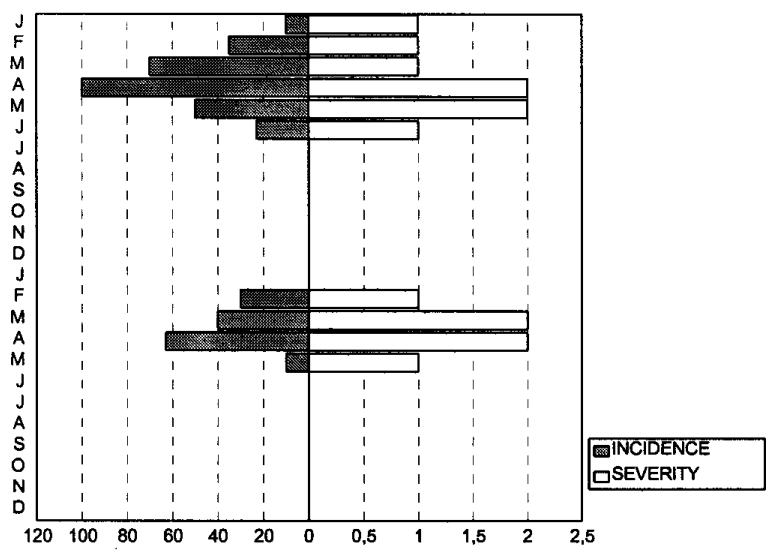

b)

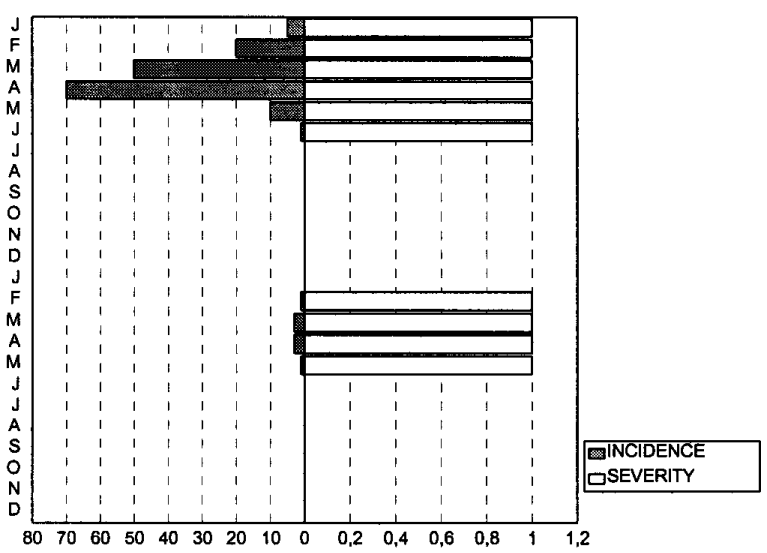

Fig. 4. Incidence and severity of Uromyces loti in leaflets of Lotus tenuis a) in associate growth with $P$. quadrifarium plants, b) growing in the area between $P$. quadrifarium plants.

the quality of paja colorada (Ojima et al. 1990, Garcìa 1992). The replacement of broad leaves weeds by forage legumes also improves the primary productivity and forage quality of native grasslands (Quinos, et al. 1994, De Battista and Miller 1995, Colabelli and Miñón 1993, Teglia et al. 1992, Montes and Cauhépé 1985).

\section{Diseases in Lotus tenuis}

Four fungal diseases were found on lotus plants throughout the experiment: leaf spot (Botrytis cinerea Pers.) in leaflets and stems, the disease did not injure more than $20 \%$ of plants and the severity never reached grades above 1 in leaflets and stems. Cold and moist weather was coincident with these symptoms (Fig 3). Rust
(Uromyces loti Blytt.) was found also on lotus leaflets and stems. Lotus plants growing in close proximity to paja colorada exhibited high rust incidence $(100 \%$ with and severity grade 2) whereas for plants growing in the area between paja colorada the incidence was reduced $(70 \%$ and severity grade 1). During February and May 1995, another rust attack was registered (Figs. 3 and 4).

Fusarium spp. Link ex Fr., (predominantly $F$. oxysporum Schlecht.), affected $20-30 \%$ of roots and stems during November 1995 (14 months after burning) with a grade 3 severity. In April 1996, the incidence was $90 \%$ and the severity was also grade 3 . Although the incidence was high, the disease did not cause plant death.
The leaf spot caused by Stemphylium sp. Wallroth, affected $30 \%$ of leaflets with the more severe attacks in the summer months. The location of lotus plants affected the severity of attack with grades 2 to 3 found in lotus plants growing in associated growth with paja colorada, but only grade 1 in the lotus growing between paja colorada plants.

\section{Conclusions}

(1) The postburn seedbed was very favorable for lotus germination and establishment. After 29 months of treatments of burning and seeding, lotus reached a cover of $20 \%$; paja colorada and bare ground cover decreased significantly during the same period.

(2) Lotus showed a high competitive ability with the annual broad-leafed weeds. The most effective chemical control was obtained with 2,4-DB formulated pure or mixed with dicamba.

(3) Lotus increased markedly the forage quality of the pasture due to its high crude protein content.

(4) Four fungus diseases were found: Botrytis and Stemphylium leaf spots, leaf and shoot rust and Fusarium wilt. However, they caused only light damage and did not impair lotus germination or establishment.

\section{Literature Cited}

Braun-Blanquet, J.J. 1979. FitosociologÌa, Bases para el estudio de las comunidades vegetales. Madrid, Edición Blume, 820 pp.

Colabelli, M.R. and D.P. Miñon. 1993. Intersiembra de leguminosas en pasturas degradadas en suelos agrìcolas del sudeste bonaerense. Revista Argentina de Producción Animal, 13(3-4), 225-233.

Dall Bello, G. and S.M. Wolcan. 1992. Enfermedades del Lotus tenuis. Congreso Argentino del género Lotus. Intech. Pcia. de Bs. As. Argentina.

De Battista, J.P. and O. Miller. 1995. Siembra en cobertura de leguminosas sobre el tapiz vegetal. Revista Argentina de Producción Animal, 15, Sup 1, 303-305.

Garcìa, F.O. 1992. Carbon and nitrogen dynamics and microbial ecology in tall grass prairie. PhD. Diss. Kansas State Univ. Manhattan. Kan.

James, C. 1971. A manual of assessment keys for plant diseases. Canada Dept. of Agr., publication 1458.

INTA-CIRN. 1989. Mapa de suelos de la Provincia de Buenos Aires. Secretarìa de Agricultura, Ganaderìa y Pesca, Proyecto PNUD, Bs. As., Argentina 85/019, 525 p.g. 
Montes, L. and M.A. Cauhèpè. 1985. Intersiembra de Lotus tenuis en cobertura. Revista Argentina de Producción Animal, 5(5-6), 313-321.

Ojima, D.S., W.J. Parton, D.S. Schimel, and C.E. Owensy. 1990. Simulated impacts of annual burning on prairie ecosystems. pp. 118-132. In: S. L. Collins and L. L. Wallace. (Editors) "Fire in North American Tall Grass on prairies", Univ. of Oklahoma Press, Norman, Okla., USA.

Ortega, E.Z. and P. Laterra. 1995. Impacto de Lotus tenuis sobre la abundancia de Carduus acanthoides y Cirsium vulgare en pajonales quemados de Paspalum quadrifar ium. Res'menes de la XVII Reunión Argentina de EcologÌa, Mar del Plata.
Quinos, P., P. Insausti, and A. Soriano. 1994. Papalum dilatatum responde a la vecindad de Lotus tenuis en la Depresión del Salado. Revista Argentina de Producción Animal. Vol 14, Sup 1.

Sacido, M., L. Hidalgo and M. A. Cauhèpè. 1995. Efecto del fuego y la defoliación sobre el valor nutritivo de matas de paja colorada (Paspalum quadri farium) Revista Argentina de Producción Animal, 15, Sup 1, 143-147.

Teglia, J., A. Garcìa Espil and M.C. Saucede. 1992. Incorporación de especies forrajeras en pastizales mediante distintas m.quinas intersembradoras. Revista de la Facultad de Agronomìa. Tomo 14 (3): 285-289.
Thornthwaite, C. and J. Mather. 1957. Instructions and tables for computing potencial evapotranspiration and water balance. Drexel Institute of Technology, Published In Climatology, Vol. X, N 3. Centerton. (Trad. Castellana por A. Rodriguez Saenz y G. Juarez. INTA, Instituto de Suelos y Agrotecnia, Tirada Interna $\mathrm{N}^{\circ} 46$, Buenos Aires, 1967.)

Vervoorst, F.B. 1967. Las comunidades vegetales de la Depresión del Salado (Prov. Bs. As.). La vegetación de la República Argentina VII. INTA. Serie Fitogeográfica $\mathrm{N}^{0} 7$. Buenos Aires.

Wolcan, S.M. and G. Dall Bello. 1988. Colletotrichum destructivum OíGara causal agent of a new disease on Lotus tenuis Walst. et Kit. Agronomie: 8, 741- 744 